\title{
Czasopisma tatarskie jako źródło do analizy oświaty Tatarów w latach 1918-1939
}

\section{Wprowadzenie}

Tatarzy przybyli na tereny Wielkiego Księstwa Litewskiego za sprawą księcia Witolda z nękanej wewnętrznymi konfliktami Złotej Ordy. Jako waleczne wojsko, stosujące znane sobie techniki walki wpisali się też w karty historii Polski, walcząc o jej interesy i niepodległość ${ }^{1}$. Obecnie w Polsce mieszka około 5 tys. Tatarów, którzy pomimo znacznego zasymilowania się z kulturą polską utrzymali poczucie swej odrębności religijnej i etnicznej, stając się perłą polskiego Orientu i stanowiąc przykład grupy o wielowymiarowej tożsamości. Niewątpliwie do zachowania przez tyle wieków odrębności kulturowej Tatarów przyczyniły się procesy oświatowe, szczególnie zintensyfikowane w okresie międzywojennym.

W Drugiej Rzeczypospolitej Tatarzy byli jedną z mniej licznych grup etniczno-wyznaniowych². Zamieszkiwali szczególnie tereny Kresów Wschodnich, największe skupiska znajdowały się w województwie wileńskim i nowogródzkim³.

* Dr, Zakład Historii Wychowania, Wydział Pedagogiki i Psychologii, Uniwersytet w Białymstoku, 15-328 Białystok, ul. Świerkowa 20.

${ }^{1} \mathrm{Na}$ temat historii Tatarów zob.: P. B or a w s k i, A. D u b iń s k i, Tatarzy polscy. Dzieje, obrzędy, legendy, tradycje, Warszawa 1986; J. Ty s z k i e w i c z, Tatarzy na Litwie i w Polsce. Studia z dziejów XIII-XVIII w., Warszawa 1989; t e nż e, Z historii Tatarów polskich 1794-1944, Pułtusk 2002; S. K r y c z y ń s k i, Tatarzy litewscy. Próba monografii historyczno-etnograficznej, Gdańsk 2000 (reprint z 1938 r.); A. M i ś k i e w i c z, Tatarzy polscy 1918-1939, Warszawa 1990; A. K o n o p a c k i, Życie religijne Tatarów na ziemiach Wielkiego Księstwa Litewskiego w XVI-XIX wieku, Warszawa 2010.

2 Według danych Muzułmańskiego Związku Religijnego wszystkich muzułmanów w 1925 r. było 5805 osób, zaś w 1935 r. ich liczba zmalała do 5425, Archiwum Akt Nowych, Ministerstwo Wyznań Religijnych i Oświecenia Publicznego [dalej: AAN, MWRiOP], sygn. 1473, k. 53.

${ }^{3}$ W 1925 r. województwo wileńskie zamieszkiwało 2464 muzułmanów, zaś w 1935 r. ich liczba zmniejszyła się do 2197 osób. W samym Wilnie mieszkało około 300 muzułmanów. Duże osady tatarskie znajdowały się w powiecie wileńsko-trockim (m.in. Sorok Tatary, Niemież) oraz w brasławskim 
W Wilnie znajdowała się siedziba Muzułmańskiego Związku Religijnego powołanego w 1925 r., na czele którego stał dr Jakub Szynkiewicz, który jako mufti reprezentował całą muzułmańską społeczność i odpowiadał za kwestie religijne. W 1925 r. powołano Związek Kulturalno-Oświatowy Rzeczypospolitej Polskiej (dalej: ZKOTRP), którego celem działalności było polepszenie sytuacji gospodarczej, społecznej, moralnej i kulturowej zjednoczonego społeczeństwa tatarskiego ${ }^{4}$.

Okres międzywojenny był niezwykle ważny dla tej grupy z racji podejmowanych działań oświatowych, które kształtowały elitę tatarską odpowiedzialną za kreowanie kierunku rozwoju całej społeczności. W latach trzydziestych XX w. oświata tatarska zaczęła przybierać już konkretne kierunki działań 5 . Jedną z form działalności kulturalno-oświatowej były wydawnictwa i prasa tatarska („Rocznik Tatarski”, „Życie Tatarskie”, „Przegląd Islamski”) wydawana przez ZKOTRP. Struktura i profil czasopism były zróżnicowane i zdeterminowane charakterem działalności organu wydającego. Nadrzędnym, wspólnym celem wszystkich czasopism było szerzenie oświaty oraz wychowanie w duchu tatarskim. Skierowane do różnych grup odbiorców przybliżały zagadnienia kulturowe dla społeczności muzułmańskiej, poprzez artykuły Tatarzy przekazywali swojej społeczności informacje i kształtowali charakter etniczny grupy.

Czasopisma były jedynym źródłem wiedzy z zakresu religii i kultury tatarskiej oraz problemów ówczesnego świata. W celu prześledzenia znaczenia oświatowego czasopism tatarskich trzeba poddać ich treści analizie.

\section{„Rocznik Tatarski”}

Czasopismem propagującym wiedzę o społeczności tatarskiej był „Rocznik Tatarski” wydawany jako organ Rady Centralnej Związku Kulturalno-Oświatowego Tatarów Rzeczypospolitej. Pomimo nazwy nie ukazywał się rokrocznie, jako wydawnictwo nieperiodyczne stanowił swoisty almanach. W okresie między-

\footnotetext{
(Widze). Liczebna była muzułmańska gmina dokszycka (345 osób), do której należeli muzułmanie z powiatów dziśnińskiego, wilejskiego i postawskiego. Równie licznie zamieszkiwali Tatarzy województwo nowogródzkie, gdzie w 1925 r. było 2091 osób, AAN, MWRiOP, sygn. 1473; k 53; L. K r a w i e c, J. J. To c h t e rm a n n, Tatarzy w Polsce, Nakładem Dziennika Urzędowego Okręgu Szkolnego Wileńskiego Bezpłatny Dodatek do Nr 2 Dziennika Urzędowego K. O. S. Wileńskiego, Wilno 1936, s. 14; S. B a z a r e w i c z, Przyczynek do statystyki muzułmańskiej parafii Dokszyckiej, „Życie Tatarskie"1935, nr 12, s. 17.

${ }^{4}$ Statut Związku Kulturalno-Oświatowego Tatarów Rzeczypospolitej Polskiej, Litewskie Centralne Archiwum w Wilnie [dalej: LCAP], sygn. f. 53, ap. 23, b. 1798, k. 7-13.

${ }^{5} \mathrm{Na}$ temat zróżnicowanych form oświaty tatarskiej w okresie międzywojennym powstała praca doktorska U. W r ó b l e w s k i e j - Oświata Tatarów polskich w latach 1918-1939 (maszynopis, 2009). Trud ukazania życia społecznego Tatarów podjął A. M i ś k i e w i c z w pracy Tatarzy polscy 1918-1939. Życie społeczno-kulturalne i religijne, Warszawa 1990; J. Mizgalski w artykule Oświata wśród Tatarów w Polsce międzywojennej, z. V, Prace Naukowe Wyższej Szkoły Pedagogicznej w Częstochowie, Częstochowa 1998 przedstawił ogólne kierunki rozwoju oświaty tatarskiej.
} 
wojennym ukazały się trzy tomy „Rocznika Tatarskiego”, nad którymi pracował redaktor - Leon Najman Mirza Kryczyński oraz komitet redakcyjny - Konstanty Achmatowicz z Wilna, Dawid Janowicz-Czaiński ze Słonimia, Olgierd Najman-Mirza Kryczyński z Wilna, Sulejman Murza-Murzicz z Nowogródka. „Rocznik Tatarski” był kontynuacją działalności oświatowej podjętej przez Tatarów studiujących przed 1918 r. w Petersburgu, był „owocem doniosłego prądu społecznego, który powstał wśród Tatarów litewskich [...]. Kolebką tego ruchu był Petersburg, gdzie w latach 1905-1910, pod wpływem pierwszych powiewów wolności, powstało akademickie koło Tatarów litewskich, składające się mniej więcej z 20 studentów różnych wyższych uczelni” wiła dla Leona Kryczyńskiego uwieńczenie jego wcześniejszej działalności społecznej i badawczej8.

„Rocznik Tatarski” jako wydawnictwo naukowe i literackie dotyczyło tradycji, historii, etnografii i związku Tatarów z kulturą polską.

Pierwszy tom koncentrował się głównie na sprawach związanych z historią i przeszłością Tatarów, podkreślano ich udział w walkach o interesy Rzeczypospolitej ${ }^{9}$, dominowały zagadnienia „stosunku Tatarów polskich do ich przybranej ojczyzny"10. Natomiast przewodnią myślą oświatową tomu drugiego było uwydatnienie i naukowe zobrazowanie stosunków politycznych, kulturalnych, wyznaniowych [...] Tatarszczyzny polskiej ze światem Islamu, a zwłaszcza z jej tatarsko-turecką praojczyzną ${ }^{11}$. Drugi tom „Rocznika Tatarskiego” zawierał artykuły nacechowane ideą panturkizmu oraz prometeizmu i podkreślał znaczenie Tatarów polskich w polityce państwa jako łączników ze światem muzułmańskim ${ }^{12}$.

6 Tom pierwszy wydano w 1932 r. w Wilnie, drugi w 1935 r. w Zamościu, zaś trzeci w roku 1938 w Warszawie. Czwarty tom „Rocznika Tatarskiego” był przygotowany do druku a Olgierd Kryczyński uzyskał z Min. WRiOP dofinansowanie w wysokości 1500 zł. Ostatni tom został zniszczony przez władze sowieckie w listopadzie 1939 r., M. K o n o p a c k i, Leon Najman Mirza Kryczyński, „Przegląd Orientalistyczny" 1964, nr 1, s. 27-37; J. Ty s z k i e w i c z, Olgierd, Leon i Stanisław Kryczyńscy, działacze kulturalni i badacze przeszłości Tatarów, „Rocznik Tatarów Polskich” 1993, t. I, s. 11.

7 Od Redakcji, „Rocznik Tatarski” 1932, t. I, s. XIII.

8 Już W Petersburgu na redaktora planowanej publikacji tatarscy studenci wybrali Leona N. M. Kryczyńskiego, który w Kole Akademików Tatarów Polskich pełnił funkcję sekretarza i rozpoczął zbieranie materiałów do planowanego pisma. Por. J. T y s z k i e w i c z, Leon Kryczyński jako redaktor „Rocznika Tatarskiego” w latach 1930-1939, „Życie Muzułmańskie” 1988, nr 8, s. 33-39; t e n ż e, Dorobek historyczny Leona i Stanisława Kryczyńskich, [w:] Środowisko historyczne II Rzeczypospolitej, cz. II, red. J. Maternicki, Warszawa 1987, s. 371-384.

9 T. K o w a I s k i, Nieco o wpływie tureckim na język Polaków z Adampola; H a d z y S e r a ja S z a p s z ał, O zatraceniu języka ojczystego przez Tatarów w Polsce; S. K r y c z y ń s k i, Generał Józef Bielak (1741-1794); A. A c h m a t o w i c z, Zarys stanu prawnego wyznania muzułmańskiego w byłej Rosji i współczesnej Polsce; L. K r y c z y ń s k i, Tatarzy litewscy w wojsku polskim w powstaniu 1831 roku; V. J., Pułk Tatarski ułanów imienia Mustafy Achmatowicza (1919-1921); T. S t r y k i e n i c z-Ko r z o n, Szkic historyczny o Tatarach litewskich w Mińsku Litewskim i jego okolicach; M. R a w it a-W ha n o w s k i, Tatarzyn Temruk-Szymkowicz indygeną polskim, „Rocznik Tatarski” 1932, t. I.

10 Od Redakcji, „Rocznik Tatarski” 1935, t. II, s. XXI.

11 Tamże.

${ }^{12}$ L. N. M. K r y c z y ń s k i, Tatarzy polscy a Wschód muzułmański; J. T a lk o-H ry n c e w i c z, Tatarzy litewscy a eurazjanizm; J. S z y n k i e w i c z, Literatura religijna Tatarów litewskich i jej pochodzenie; O. Gó r k a, Uwagi orientacyjne o Tatarach polskich i obcych; A. Z a j ą c z k o w s k i, 
Ostatni wydany przed wojną trzeci tom „Rocznika Tatarskiego” był w całości przygotowaną przez Stanisława Kryczyńskiego monografią historyczno-etnograficzną opisującą dzieje Tatarów polsko-litewskich, stanowiącą do czasów obecnych jedną z fundamentalnych pozycji z zakresu tatarszczyzny.

Wychowanie patriotyczne poprzez przekaz wartości historycznych można odnaleźć w publikowanych biogramach bohaterów tatarskich zasłużonych w walkach o wolność Polski m.in. Jakóba Azulewicza, Stefana Bielaka czy porucznika Aleksandra Kryczyńskiego ${ }^{13}$. Przypominanie czynów heroicznych bohaterów tatarskich godnych naśladowania miało wymiar wychowawczy. Jednocześnie podkreślano odrębność kulturową Tatarów, akcentując ich udział w historycznym tworzeniu Drugiej Rzeczypospolitej ${ }^{14}$. Natomiast gen. Maciej Sulkiewicz był ukazywany jako polski Tatar walczący o wolność ludów zniewolonych przez Rosję ${ }^{15}$. Ze względu na wartość kulturotwórczą warto także zwrócić uwagę na teksty Stanisława Dziadulewicza, który w cyklu Notatki heraldyczne udowadniał pochodzenie tatarskie i ukazywał genealogię Henryka Sienkiewicza ${ }^{16}$.

W „Rocznikach Tatarskich” w części literackiej publikowano wiersze autorstwa Tatarów, które w sposób poetycki ukazywały jednocześnie ich tęsknotę za dawną „stepową” ojczyzną i przywiązanie do Polski ${ }^{17}$.

Komitet redakcyjny „Rocznika Tatarskiego” konsekwentnie i świadomie dobierał artykuły i rozprawy. Redaktor naczelny Leon Kryczyński potrafił nakłonić do współpracy wybitnych specjalistów z zakresu orientalistyki, historii, antropologii czy krajoznawstwa ${ }^{18}$. Wśród inteligencji tatarskiej (prawnicy, wojskowi, urzęd-

Elementy tureckie na ziemiach polskich; A. Z i h n i, Z dziejów korespondencji dyplomatycznej między Krymem a Polską w XVII w., „Rocznik Tatarski” 1935, t. 2.

${ }^{13}$ Aleksander Murza Kryczyński, podporucznik II-ej brygady jazdy wojsk litewskich w korpusie generała Jakuba Jasińskiego, S. K r y c z y ń s k i, Życiorysy zasłużonych muślimów. Porucznik Aleksander Kryczyński, „Rocznik Tatarski” 1935, t. II, s. 416-417.

${ }^{14}$ Leon Kryczyński przedstawił Aleksandra Sulkiewicza jako narodowego bohatera, który pochodził ze starego tatarskiego rodu Ałczanów i jako wierny przyjaciel Józefa Piłsudskiego całe swoje życie poświęcił na konspiracyjną pracę wspierającą działania PPS-u. L. K r y c z y ń s k i, Aleksander Sulkiewicz (Czarny Michał) (1867-1916), „Rocznik Tatarski” 1932, t. I; W podobnej konwencji pisali również: I. A c h m a t o w i c z, Obrona Płocka w roku 1920 (wspomnienia uczestnika), „Rocznik Tatarski” 1932, t. I; L. M u r z a N a j m a ń s k i, Przyczynek w sprawie stosunku Tatarów Litewskich do powstania 1863 roku, S. K, Tatarzy litewscy w armji Fryderyka Wilhelma II, „Rocznik Tatarski” 1935, t. II; J. K o r y c k i, Kruszyniany, „Rocznik Tatarski” 1935, t. II.

${ }^{15}$ Arsłan-Bej w jednym z artykułów przypomniał generała Macieja Sulkiewicza pochodzącego z zasłużonego rodu tatarskiego, Naczelnika Rzeczypospolitej Krymskiej (1928) i patriotę muzułmańskiego, który poświęcił swoje życie w imię wolności narodów tatarskich. „Rocznik Tatarski” 1932, t. I, s. $246-255$.

${ }^{16} \mathrm{~S}$. D z i a d u l e w i c z, Notatki heraldyczne 1. Nowe dane o tatarskim pochodzeniu H. Sienkiewicza, 2. Szachmancerowie herbu własnego, „Rocznik Tatarski” 1935, t. II.

17 W tomie I „Rocznika Tatarskiego” z 1932 r. ukazały się wiersze: S. K ry czyń ski, O, osądź..., Akret, Refleksje; t e n ż e, Umarłym; S. R a d w a n, Wspomnienie; zaś w tomie II „Rocznika Tatarskiego" z 1935 r. wydrukowano wiersz Józef Wierzyński, Selim i Hania.

${ }^{18}$ W „Rocznikach Tatarskich” pojawiły się teksty: prof. Tadeusza Kowalskiego, dr. Abdullaha Soysala Zihniego (Kraków); dr. Jakuba Szynkiewicza, dr. Saraj Szapszała (Wilno); prof. Ananiasza Zajączkowskiego (Instytut Orientalistyczny Uniwersytetu Warszawskiego); dr. Stanisława Szachno-Romanowicza (Archiwum Główne Akt Dawnych w Warszawie); Alego Woronowicza (absolwenta Instytutu Orientalistyki Uniwersytetu Lwowskiego oraz Uniwersytetu Al-Azhar w Kairze); prof. Olgierda 
nicy) zamawiał artykuły, które wpisywały się w koncepcję i założenia „Rocznika Tatarskiego"19. Leon Kryczyński, dbając o wysoki poziom almanachu konsultował prace z prof. Stanisławem Kościałkowskim z Uniwersytetu Stefana Batorego w Wilnie. Podczas przygotowywania „Roczników Tatarskich” redakcja współpracowała ze społecznością karaimską, w spornych kwestiach orientalistycznych szczególnie cenna była pomoc merytoryczna hachana karaimskiego J. H. Szapszała $^{20}$. Wartościowe merytorycznie rozprawy naukowe z zakresu historiografii Tatarów polsko-litewskich opracowywał i publikował na łamach czasopisma Stanisław Kryczyński, daleki krewny braci Kryczyńskich ${ }^{21}$.

Treści zawarte w „Rocznikach Tatarskich” poprzez oświatowy charakter i wychowawcze oddziaływanie kształtowały wielowymiarową tożsamość Tatarów. Jednym z obszarów tematycznych były zagadnienia dotyczące przeszłości Tatarów muzułmanów powiązanej ze wspólną historią Polski, co kreowało wymiar narodowy. Natomiast inne artykuły i rozprawy nacechowane ideą panturkizmu uświadamiały Tatarom wspólną przynależność do tiurko-tatarskiej grupy etnicznej.

Niestety w okresie międzywojennym Radzie Centralnej ZKOTRP udało się wydać jedynie trzy tomy niezwykle ważnych pod względem oświatowym rozpraw naukowych ${ }^{22}$. Warto też zwrócić uwagę na fakt, że „Roczniki Tatarskie” nie docierały do szerokiego kręgu odbiorców tatarskich, wobec czego ich działanie wychowawcze było ograniczone. Wobec problemów finansowych liczba egzemplarzy „Roczników Tatarskich” była niewystarczająca (tom I wydrukowano w 1000 egzemplarzy, zaś już tom II zmniejszono do 250). Zapewne również cena pojedynczego egzemplarza uniemożliwiała zakup czasopisma przez uboższą grupę Tatarów. Ze względu na naukowy język i wysoki poziom merytoryczny rozpraw

Górki (Warszawa), Jana Talko-Hryncewicza, M. Rawita-Witanowskiego, M. Żdana (krajoznawcy i badacze regionalni).

19 Do „Rocznika Tatarskiego” przygotowywali rozprawy przedstawiciele społeczności tatarskiej m.in. Aleksander Achmattowicz, Stanisław Dziadulewicz, Ch. Muchammed G. Wajsow, Iskander Achmatowicz, Arałan Baj, Stefan Tuhan-Baranowski, Wassan-Girej Dżabagi, Mustafa Aleksandrowicz.

${ }^{20}$ S. Kryczyński, pracując nad biografią Aleksandra Kryczyńskiego beja barskiego (1630-1673) miał wątpliwości etymologiczne i zapytywał Szapszała o znaczenie nazwy Lipków, nie dowierzając wyjaśnieniom S. Tuhan-Baranowskiego (Skąd powstała nazwa Lipków, „Wschód - Orient” 1930, nr 3-4, s. 46-56), który uważał, że nie jest to słowo tureckie i pochodzi od miejscowości Lipczany). Kryczyński pozostawał przy tym, że jednak jest to słowo tureckie (Lipek) tak jak Jemen (wyborowy kozak), Serdeniata (piechota zaporowa), Hajdamaki (rozbójnicy kozaccy), Denek (kozak w kij uzbrojony) lub Lipek to wyraz tatarski tak jak Kozak. Jest to podobno w książce Imirinowa Chanat krymski, której nie posiadał i prosił Szapszała o radę (pismo z dn. 14 IX 1933), BLAN, sygn. f. 143-705, k. 2.

${ }^{21}$ Wspólnie z Leonem Kryczyńskim w 1930 r. prowadził badania terenowe w ośrodkach tatarskich Wileńszczyzny i Nowogródczyzny, spisywał dzieje i historię rodzin tatarskich oraz gmin muzułmańskich na Kresach. Nieoficjalnie pełnił funkcję sekretarza „Rocznika Tatarskiego”, o czym świadczy korespondencja, którą prowadził z redaktorem naczelnym czasopisma. Leon Kryczyński w zdolnym i ambitnym młodym historyku pokładał duże nadzieje na przyszłość, przygotowując go do roli kontynuatora swoich działań kulturalno-oświatowych. Stanisław Kryczyński, odrzucając możliwość pracy na uczelni, swoje umiejętności wykorzystał na badania historyczno-etnograficzne społeczności tatarskiej.

${ }^{22}$ Leon Kryczyński ze względów zawodowych trzykrotnie zmieniał miejsce swojego zamieszkania, co bezpośrednio utrudniało oraz opóźniało prace redakcyjne. Ograniczone możliwości finansowe uniemożliwiały systematyczne drukowanie tak obszernego czasopisma, gdzie tom I liczył 370 stron, tom II - 518 stron, tom III zaś -420 stron. 
„Roczniki Tatarskie” nie miały możliwości propagowania i upowszechniania wiedzy wśród całej społeczności tatarskiej. Czasopismo miało raczej elitarny charakter i miało ograniczoną możliwość dotarcia pod każdą „tatarską strzechę”. Jednak pomimo średniej powszechności należy pamiętać, że ze względu na wysoki poziom merytoryczny i faktograficzny treści „Roczniki Tatarskie” stanowią obecnie bogatą bazę źródłową z dziejów historii i znaczenia kultury tatarskiej. W porównaniu z innymi czasopismami muzułmańsko-tatarskimi okresu międzywojennego „Rocznik Tatarski” koncentrował się głównie na sprawach związanych z historią i przeszłością Tatarów. Wobec wartości edukacyjnych, rzetelnych informacji ukazujących Tatarów jako Polaków walczących o wolność ojczyzny Min. WRiOP zaleciło, aby biblioteki szkolne na kresach wschodnich posiadały w swoim księgozbiorze „Roczniki Tatarskie”.

\section{„Życie Tatarskie”}

Czasopismem o szerszym zasięgu, które rozumiało rolę Tatarów polskich jako „placówki żywego orientu na zachodzie” było „Życie Tatarskie” wydawane przez wileński oddział ZKOTRP ${ }^{23}$. Zadaniem „Życia Tatarskiego” było podniesienie kultury Tatarów na wsi i w miasteczkach, oznajmienie ich z życiem muzułmanów z całego świata, wpajanie w serca wierność i miłość ku ich ojczyźnie Rzeczpospolitej Polskiej oraz szerokie udzielanie im porad higienicznych i gospodarczych ${ }^{24}$.

Pierwszy numer pod redakcją płk. rez. Stefana Tuhan-Mirza Baranowskiego ukazał się w styczniu 1934 r. i został rozesłany gminom muzułmańskim oraz przedstawicielom społeczeństwa tatarskiego ${ }^{25}$. Forma graficzna czasopisma przez kolejne lata nie ulegała znaczącym zmianom ${ }^{26}$. Czasopismo było wydawane systematycznie każdego miesiąca, ostatni numer ukazał się w sierpniu $1939 \mathrm{r}$. (nr 8 z 1939 r.), kolejny numer 9 był już zamknięty, jednak jego wydrukowanie uniemożliwił wybuch drugiej wojny światowej. We wszystkich numerach miesięcznika można zauważyć podkreślanie działalności kulturalnej Tatarów w Drugiej Rzeczypospolitej i wyróżniający się profil społeczny i religijny czasopisma ${ }^{27}$.

Zagadnienia poruszane na łamach czasopisma można zasadniczo podzielić na dwie grupy. Część artykułów skupiała uwagę czytelnika na kwestiach związanych ze społecznością Tatarów jako „rdzennych” mieszkańców Drugiej Rzeczy-

23 „Wschód - Orient” 1934, nr 1, s. 82.

${ }^{24}$ Archiwum Oddz. PAN w Krakowie, List S. Tuhan-Mirzy Baranowskiego do profesora orientalistyki T. Kowalskiego z dnia 9 III 1934 r., Akta prof. Kowalskiego, sygn. 157, b. s.; „Życie Tatarskie” 1934, nr 2, s. 2.

${ }^{25}$ Pierwszy numer miesięcznika miał się ukazać w Wilnie już w grudniu 1933 r. jako „Głos Tatara”, w rzeczywistości została zmieniona nazwa na „Życie Tatarskie”, „Wschód - Orient” 1933, nr 3, s. 81.

${ }^{26}$ Do 1937 r. periodyk wydawany był w formacie B-5 w sztywnej tekturowej jasnozielonej okładce (wyjątkiem był numer 1 z 1936 r., gdy kolor okładki był różowy) z rysunkiem rotmistrza tatarskiego z XVII w., zaś od 1938 r. na okładce widnieje buńczuk tatarski.

27 B. H. B I a d o c h, Analiza treści prasy islamskiej w II RP, „Rocznik Tatarów Polskich” $2001 / 2002$, t. VII, s. 62. 
pospolitej. Z drugiej strony wiele miejsca poświęcono zagadnieniom związanym ze społecznością tatarską na świecie i z muzułmanami w innych państwach.

Wśród artykułów dotyczących społeczności tatarskiej znajdowały się prace historyczne, dokumentujące czyny wojenne Tatarów ${ }^{28}$. Artykuły z historii Tatarów litewskich i dziejów tatarskiego oręża wojskowego stanowiły znaczny zasób wiedzy archiwalnej i dokumentów, a publikowane były przez S. Tuhan-Mirzę Baranowskiego do 1937 r. w dwóch nieregularnie ukazujących się cyklach: „Kartki z dziejów Tatarów litewskich” oraz „Z akt wojskowych o Tatarach Litewskich ${ }^{29}$.

Kolejnym istotnym zagadnieniem wielokrotnie poruszanym na łamach miesięcznika były kwestie związane z religią muzułmańską, z dogmatami i zasadami panującymi $w$ islamie ${ }^{30}$. Wątek religijny nie dominował, skupił się na przekazaniu zasad islamu, tradycji przodków i był daleki od fanatyzmu. Artykuły z historii i teorii islamu były podstawową wiedzą dla Tatarów muzułmanów ${ }^{31}$. Do odnowy religijnej przyczynił się Ali Ismail Woronowicz, który po powrocie ze studiów w Al-Azhar w Egipcie jako imam m. st. Warszawy poprzez liczne artykuły umieszczane w „Życiu Tatarskim” podkreślał znaczenie religii i potrzebę przestrzegania zasad wyznaczonych przez islam ${ }^{32}$. Wartości moralne odnajdowali Tatarzy w powieści Ayasa Ishaky tłumaczonej z języka tatarskiego Sunetczy-Babaj33.

${ }^{28}$ Z. R o m a n o wi c zó w n a, Tatarzy w Łosośnie, „Życie Tatarskie” 1934, nr 8; S. T u h a n-B a r a n o w sk i, Tatarzy na Litwie, „Życie Tatarskie” 1936, nr 9; Wizja z przeszłości, tamże, nr 10; S. K r y c z y ń s k i, Meczety w okolicach Wilna dawniej i dziś, „Życie Tatarskie” 1934, nr 5; t e nż e, O ratowaniu zabytków tatarskich, „Życie Tatarskie” 1937, nr 10; [brak autora], Skąd powstała nazwa Lipków, „Życie Tatarskie” 1936, nr 3; A. J a c e w i c z, Zapomniana wieś tatarska Ochmatków, „Życie Tatarskie" 1936, nr 3; S. T. B a r a n o w s k i, Ze wspomnień o Czarnym Michale (Aleksandrze Sulkiewiczu), „Życie Tatarskie” 1938, nr 5.

${ }_{29}$ "W cyklu „Kartki z dziejów Tatarów litewskich” od numeru 1 z 1935 roku do numeru 12 z 1936 r. Stefan Tuhan-Mirza Baranowski umieszczał dokumenty historyczne, takie jak: Odpis podania Aleksandra Ułana z d. 20 maja 1792 r., (który) ofiarowuje się zwerbować 500 Tatarów, „Życie Tatarskie” 1935, nr 1; W ramach cyklu „Z akt wojskowych o Tatarach Litewskich (1782-1792; 1778-1792)" udostępniono: Wypisy z Xiąg Trybunału W. Xięstwa Littego, „Życie Tatarskie” 1936, nr 6; Nota Józefa Bielaka gen. Majora o potrzebie pułku jego, „Życie Tatarskie” 1935, nr 6-7; Raport Józefa Judyckiego o wtargnięcie lit. komendy ros. 1789, Patent królewski na szarżę aktualnego chorążego Mustafy Baranowskiego, „Życie Tatarskie” 1936, nr 9; Spis oficerów i towarzyszy (Tatarskich) w putkach Przedniej Straży Wojskowej w. Ks. Lit. 1786, „Życie Tatarskie” 1936, nr 10; Spis oficerów Przedniej straży Wojskowej 1786, „Życie Tatarskie 1936, nr 12; Spis oficerów 1786 pułku Przedn. Straży W. Ks. Lit.; Ferstelacja awansujących oficerów kom. Baranowskiego; Achmatowicz major melduje o aresztowaniu unteroficera wojsk rosyjskich, „Życie Tatarskie” 1937, nr 1.

${ }^{30}$ Kolejne numery do 12 w 1935 r. rozpoczynały się od wypisanych wersetów (sur) z Koranu.

${ }^{31}$ J. S z y n k i e w i c z, Tolerancja w Islamie, „Życie Tatarskie” 1934, nr 12; A. a I- Ta n t a w, Historia Islamu, (przeł. z arab. M. Aleksandrowicz), „Życie Tatarskie” 1935, nr 1; Zagadnienie śmierci w Islamie, (przedruk z „Moslemische Reuve”, tłum. Z. Romanowiczówna), „Życie Tatarskie” 1937, nr 6; Sunnici i szyici, „Życie Tatarskie” 1939, nr 6; Em, Boże Narodzenie, Święcone czy Bajram?, „Życie Tatarskie" 1939, nr 5.

${ }^{32}$ A. I. W o r o n o w i c z, Istota Islamu. Bajram, „Życie Tatarskie” 1934, nr 4, s. 7; Nowa droga, tamże, nr 9; Język Muślimów polskich, tamże, nr 11; Islam a kobieta, „Życie Tatarskie” 1936, nr 2; Wierzmy i bądźmy ofiarni, „Życie Tatarskie” 1938, nr 1; Czcijmy ojców naszych, tamże, nr 9; O oblicze religijne muślimów polskich, „Życie Tatarskie” 1939, nr 3; Kurs nauki Religi Islamu dla hodżych i duchowieństwa muzułmańskiego, „Życie Tatarskie” 1939, nr 8.

${ }^{33}$ I. A y a s, Sunetczy-Babaj, „Życie Tatarskie” 1938, nr 8; 1939, nr 8; Ayasa Ishaky był tatarskim nadwołżańskim dziennikarzem i powieściopisarzem oraz energicznym działaczem w Charbinie 
Wschodnie i arabskie aforyzmy publikowane na łamach miesięcznika stanowiły kompendium wiedzy o zasadach islamskich ${ }^{34}$.

Czasopismo miało służyć przede wszystkich samej społeczności tatarskiej, dlatego też umieszczano w nim artykuły poruszające kwestie społeczne, ekonomiczne i gospodarcze Tatarów w Drugiej Rzeczypospolitej.

W „Życiu Tatarskim” ukazywały się artykuły z poradami wychowawczymi dla rodzin, podkreślające znaczenie domu rodzinnego w muzułmańskiej tradycji religijnej ${ }^{35}$. Wobec znacznego wskaźnika śmiertelności wśród dzieci w przygotowanym przez miesięcznik cyklu „Hygjena w domu” zwrócono uwagę na zachowanie zasad higieny i podkreślono znaczenie wychowania fizycznego w rozwoju dzie$\mathrm{ci}^{36}$. Szczególną rolę w sprawnym funkcjonowaniu rodziny przypisywano kobiecie, która jako „matka i gospodyni” miała stać na straży tradycyjnych tatarskich wartości ${ }^{37}$. W periodyku poruszano problemy społeczne, które dotyczyły również samych Tatarów, szczególnie kwestia małżeństw mieszanych i rozwodów wywołała żywą dyskusję prowadzoną na łamach czasopisma ${ }^{38}$. Od 1934 r. cyklicznie publikowano w ramach „Porad gospodarczych” innowacyjne pomysły, które miały usprawnić pracę na gospodarstwie ${ }^{39}$.

Autorzy w swoich artykułach informowali o życiu kulturalnym i religijnym społeczności tatarskiej skupionej wokół gmin muzułmańskich ${ }^{40}$. W drugim numerze

(Chiny północne pod panowaniem Japonii Mandżu-Kuo). W latach trzydziestych odwiedził Wilno. L. N. M. K r y c z y ń s k i, Historia meczetu w Wilnie, „Przegląd Islamski” 1937, nr 1-3, s. 31.

${ }^{34}$ Aforyzmy wschodnie ukazały się w „Życiu Tatarskim” w nr 6 z 1935 r., zaś Aforyzmy arabskie opublikowano w „Życiu Tatarskim” nr 8 z 1935 r. Według Sylwestra Milczarka aforyzmy redakcja „Życia Tatarskiego" zaczerpnęła z aforyzmów Remigiusza Kwiatkowskiego, por. S. M i l c z a r e k, "Życie Tatarskie» (omówienie czasopisma), „Rocznik Tatarów Polskich” 1993, t. I, s. 112.

${ }^{35}$ M. G e m b i c k i, Szukajcie a znajdziecie, „Życie Tatarskie” 1938, nr 4; Wychowanie rodzinne, „Życie Tatarskie” 1938, nr 7; E s th e, Wychowanie dzieci, „Życie Tatarskie” 1939, nr 5.

${ }^{36}$ Wychowanie fizyczne dzieci do lat 2-ch, „Życie Tatarskie” 1934, nr 2; A. M u c h ó w n a, Wychowanie fizyczne dziecka od 2 do 7 lat, tamże, nr 3; E. T. B a r a n o w s k i, Znaczenie wychowania fizycznego, „Życie Tatarskie” 1934, nr 5.

${ }^{37}$ M. C., Głos młodej matki, „Życie Tatarskie” 1934, nr 2; E. M i ś k i e w i c z ó w n a, Obowiązki kobiety w dobie obecnej, „Życie Tatarskie” 1934, nr 12; Dola muzułmanki w Polsce, „Życie Tatarskie” 1936, nr 6-7; Kobieta gospodyni, „Życie Tatarskie” 1937, nr 1; S. T. B a r a n o w s k i, Muzułmanka w Polsce, „Życie Tatarskie" 1939, nr 5.

${ }^{38}$ A. M u c hówn a, Alkoholizm, „Życie Tatarskie” 1934, nr 5; Alkoholizm, „Życie Tatarskie” 1934, nr 8. Zagadnienie rozwodów i małżeństw mieszanych było wielokrotnie poruszane na łamach „Życia Tatarskiego”, por. S. T. B a r a n o w s k i, Mieszane małżeństwa, „Życie Tatarskie” 1938, nr 11; M. G e m b i c k i, Nasze małżeństwa i rozwody, „Życie Tatarskie” 1939, nr 2; S. T. B a r a n o w s k i, Jeszcze o rozwodach, tamże, nr 3; Kto winien? O małżeństwach mieszanych, tamże, nr 4; A. J e l j a s z e w i c z, Odpowiedź na «Jeszcze o rozwodach», tamże, nr 4.

${ }^{39}$ W cyklu „Porady gospodarcze” redagowanym przez H. S. podejmowano następujące zagadnienia z agrotechniki i hodowli zwierząt: Ogórki, Najlepsze pasze dla krów mlecznych, „Życie Tatarskie" 1934, nr 2; Wyroby Iniane, roboty wiosenne w sadach, tamże, nr 3; Sposoby polepszania zboża siewnego, jak zmusić drzewa nie owocujące do owocowania, miód, tamże, nr 4; Owoce, grzyby, kożuchy, tamże, $\mathrm{nr} 7$.

${ }^{40}$ A. S z e h i d e w i c z, Tatarzy Wołyńscy, „Życie Tatarskie 1935, nr 8; M. B a j r a s z e w s k i, Tatarzy Słonimscy, „Życie Tatarskie” 1934, nr 6; A. M u r z a M u r z i c z, O koloni polskich Tatarów Turcji, „Życie Tatarskie” 1938, nr 6; M. G e m b i c k i, O emigracji Tatarów polskich do Turcji, tamże, nr 8; Z życia Tatarów nowogródzkich, „Życie Tatarskie” 1939, nr 5; Z. M i ś k i e w i c z ó w n a, Lahi w Mirze, „Życie Tatarskie” 1934, nr 10. 
w 1939 r. pojawił się dział „Z kroniki życia towarzyskiego”, gdzie umieszczono informacje o zawartych związkach małżeńskich ${ }^{41}$. Dzięki cyklicznej „Kronice z kraju i ze świata" Tatarzy dowiadywali się o istotnych wydarzeniach państwowych i zagranicznych ${ }^{42}$. Wobec narastających konfliktów, jakie przeżywała Europa szykująca się już do kolejnej wojny, od 1938 r. w „Życiu Tatarskim” pojawił się cykl „Przegląd Polityczny”, którego celem było informowanie o najważniejszych wydarzeniach politycznych ówczesnego świata ${ }^{43}$.

Tatarzy polscy jako wyznawcy islamu byli geograficznie oddaleni od centrów religii muzułmańskich, dlatego na łamach miesięcznika zamieszano artykuły, które przybliżały społeczności tatarskiej przestrzeń kulturową innych społeczności muzułmańskich na świecie. Publikowane sprawozdania z podróży do państw pozaeuropejskich pozwalały czytelnikowi przenieść się do zupełnie innej rzeczywistości, chociaż niejasnej i niezmiernie egzotyczneje ${ }^{44}$.

Tatarzy, czytając „Życie Tatarskie”, dowiadywali się o zwyczajach, obrzędach panujących i przestrzeganych w innych społecznościach muzułmańskich ${ }^{45}$.

W każdym numerze znajdowały się artykuły poświęcone zagadnieniom społeczno-politycznym innych państw muzułmańskich walczących o wolność i suwerenność. Informowano czytelników o przeszłości i ówczesnej sytuacji politycznej w Egipcie, Turcji i innych państwach Bliskiego Wschodu ${ }^{46}$. Szczególnie wiele uwagi

${ }^{41}$ Związki małżeńskie zawarli: 1) w Nowogródku Mustafa Gembicki z Janiną Józefowiczówną, 2) w Warszawie Leon Kajman Mirza Kryczyński z Haliną Sierakowską, 3) w Wilnie Roman Kulzeman Mirza Talkowski z Marją Małachowską, 4) w Słonimie Edige Szynkiewicz z Tamarą Bielakówną, „Życie Tatarskie" 1939, nr 2, s. 23.

42 Stała rubryka „Z kraju i ze świata” zamieszczona na 2-3 stronach miesięcznika zawierała najważniejsze informacje z życia społecznego, politycznego, gospodarczego i religijnego. Kronika z kraju przedstawiała przede wszystkich ówczesną sytuację społeczności tatarskiej, informując o bieżących wydarzeniach z życia gmin muzułmańskich. Publikowano zarządzenia Mufiego, informowano o wyborach imamów i muezinów oraz relacjonowano działalność ZKOTRP i Kół Młodzieży Tatarskiej.

${ }^{43}$ Pierwszy „Przegląd Polityczny” zostaje opublikowany w nr 3 z 1938 r. i jest systematycznie drukowany w każdym kolejnym numerze „Życia Tatarskiego” do nr 8 z 1939 r. (ostatni). Redaktorem działu został Emir Tuhan-Baranowski, który opracowywał zagadnienia polityczne.

44 J. S z y n k i e w i c z, Sprawozdanie muftiego Jakuba Szynkiewicza z podróży do Egiptu, Hadżesu i Palestyny od 18.03.1930 r. do 18.07.1930 r., „Życie Tatarskie” 1935, nr 1; A. W o r o n o w i c z, Garść wrażeń z Egiptu, „Życie Tatarskie” 1935, nr 1; (b. a), Sprawozdanie z podróży do Indji w grudniu 1936 r., „Życie Tatarskie” 1936, nr 12; E. S z y n k i e w i c z, Podróż do Iranu, „Życie Tatarskie” 1937, nr 10; (b. a), Wrażenia z podróży do Indji Wschodnich Dr J. Szynkiewicza, „Życie Tatarskie” 1938, nr 8; T. M. N it te r m a n, Kasablanka i Magazem, „Życie Tatarskie” 1935, nr 10; Czarodziej w Oazie Marakesz, tamże; H. T. B a r a n o w s k a, Algieria i Oazy Saharyjskie, Abisynia, tamże, nr 9; S. Tu ha n - B a r a n o w ski, Południowo-zachodnia Azja, tamże; E s t e, Tunis - Bizerki, tamże, nr 4; F. A. O s s e n d o w s k i, O Tunisie, „Życie Tatarskie” 1938, nr 8; W Saharze, „Życie Tatarskie” 1937, nr 9; Tajemnice Afryki, „Życie Tatarskie” 1939, nr 8.

45 O Czerkiesach w Jugosławji, „Życie Tatarskie” 1936, nr 8; S. B a z a r e w s k i, Muzułmanie w Jugosławii „Życie Tatarskie” 1937, nr 2; I. Kirimil A r s I a n o glu, Tiurcy w Rumunji, „Życie Tatarskie" 1935, nr 1.

${ }^{46}$ B. R i c h t e r, Egipskie protesty, „Życie Tatarskie” 1934, nr 8; M. A l e k s a n d r o w i c z, Pismo Suuda Wielkiego do ludności Nedżranu i Jamu, „Życie Tatarskie” 1934, nr 11; t e n ż e, Kwestia arabska, „Życie Tatarskie” 1935, nr 2; t e n ż e, Anglja i Egipt w Sudanie - na marginesie konferencji Anglo-Egipskiej, „Życie Tatarskie” 1936, nr 6-7; t e n ż e, Kair - miasto kontrastów, tamże, nr 8; A. W o r o n o w i c z, Kapitulacja a Egipt, tamże, nr 9; M. A l e k s a n d r o w i c z, Kto spalił bibliotekę 
poświęcano kwestiom walk etnicznych w Rosji na obszarze kaukaskim i uralskim ${ }^{47}$. Żywo interesowano się również sytuacją rdzennych muzułmańskich grup etnicznych zamieszkujących Rosję, które podejmowały próby oddzielenia się od imperium rosyjskiego ${ }^{48}$. Napięta sytuacja etniczna i polityczna na Kaukazie wywołała ruch nacjonalistyczny w Azerbejdżanie, o czym dokładnie informowano czytelników „Życia Tatarskiego"49. Artykuły politologiczne, w których akcentowano walki narodowościowe miały zadanie informacyjne, ale również propagowanie idei prometeizmu.

W „Życiu Tatarskim” czytelnik mógł również odnaleźć wątki literackie w formie publikowanych wierszy autorstwa samych Tatarów, które były nacechowane postawą patriotyzmu wobec ojczyzny i tęsknotą za utraconą przeszłością ${ }^{50}$.

$\mathrm{Na}$ łamach periodyku wypowiadali swoje opinie przedstawiciele trzech pokoleń społeczności tatarskiej ${ }^{51}$. Wśród autorów znajdowali się emigranci ze

w Aleksandrii?, „Życie Tatarskie” 1937, nr 3; t e n ż e, Literatura Egiptu współczesnego, tamże, nr 6; S. B a z a r e w i c z, Postępy rolnictwa w Nowej Turcji, „Życie Tatarskie” 1934, nr 2; T. S z e h i d e w i c z ó w n a, Turczynka niegdyś a dziś, tamże, nr 6; Kemel Pasza a Turcja dzisiejsza, tamże, nr 11; C z e k a to w ic z, Muzyka we współczesnej Turcji, „Życie Tatarskie” 1936, nr 10; M. A le k s a n drowicz, Na pięćsetlecie Tureckiego Stambułu, „Życie Tatarskie” 1938, nr 9; A. M u rza-M u r z i c z, Kemal Atatürk i Jego Dzieło, tamże, nr 11; t e n ż e, Turcja w 13-tą rocznicę, „Życie Tatarskie” 1936, nr 12; M. A l e k s a n d r o w i c z, Sytuacja w Palestynie, „Życie Tatarskie” 1934, nr 4; S. T. B a r a n o w s k i, Żydzi a Palestyna, tamże, nr 5; M. B a ła, Zatarg Palestyński i Anglja, „Życie Tatarskie” 1936, nr 8; Persja, „Życie Tatarskie” 1934, nr 4; Ferdousi - poeta perski, tamże, nr 12; E s te, Wieś Syryjska, „Życie Tatarskie” 1936, nr 6-7; M. B a ła, Nowy Iran, „Życie Tatarskie” 1938, nr 9.

${ }^{47}$ K. Y i g i t, Przeszłość i teraźniejszość Tatarzy krymscy, „Życie Tatarskie” 1934, nr 6; t e n ż e, Krym rosyjski czy tatarski. Krym w ogniu walk narodowościowych, tamże, nr 7; A. Murza-Murzicz, Ku Wolności, „Życie Tatarskie” 1937, nr 1; A. Z. S o y s a I, Kultura Chanatu Krymskiego, tamże, nr 3; t e n ż e, Sytuacja kobiety w Chanacie Krymskim, tamże, nr 7; A. M u r z a M u r z i c z, Niezapomniany bohater Krymu Czelebi-Dżihas, tamże, nr 9; A. Z. S o y s a I, XX rocznica śmierci Czelebi Dzihan, „Życie Tatarskie” 1938, nr 3.

${ }^{48}$ M. B a ła, Republiki muzułmańskie w ZSRR, „Życie Tatarskie” 1936, nr 10; t e n ż e, Religja w ZSRR, „Życie Tatarskie" 1937, nr 1; E. T u h a n-B a r a n o w s k i, Polityka mocarstw na Wschodzie muzułmańskim, „Życie Tatarskie” 1938, nr 2; K. Y i g i t, Zarys ruchu nacjonalnego wśród narodów tiurko-tatarskich na terenie Europy Wschodniej, „Życie Tatarskie” 1937, nr 7; M. S u s z c z e w i c z, Dawne zwyczaje weselne wśród Tatarów Idel-Uralu, „Życie Tatarskie” 1936, nr 12; M. V e y s i n, Rozwój Islamu w Turkiestanie, „Życie Tatarskie” 1937, nr 2; K. S y r e w i c z, Turkiestan Wschodni, „Życie Tatarskie” 1936, nr 10; K. Y i g i t, Turkiestan zachodni, „Życie Tatarskie” 1934, nr 7.

49 J u s s u f, Pakt konfederacji kaukaskiej, „Życie Tatarskie” 1934, nr 11; Ali-Mardam-bej-Topczybaszy działacz narodowy Rosji w Baku, tamże, nr 12; M. B a ła, Prawo o Azerbejdżanie, „Życie Tatarskie" 1936, nr 3; K. Y i g i t, Nowy etap ruchu nacjonalnego w Azerbej-dżanie, tamże, nr 10; t e n ż e, Nowy etap ruchu nacjonalnego w Azerbejdżanie, „Życie Tatarskie” 1936, nr 11; M. B a ł a, Azerbejdżan, „Życie Tatarskie” 1937, nr 9; t e n ż e, Ruch nacjonalistyczny w Azerbejdżanie, „Życie Tatarskie” 1938, nr 1; A. S z c z e r b a, Początki nacjonalizmu Azerbejdżanu, „Życie Tatarskie” 1939, nr 2.

${ }_{50}$ P. P a w I o w i c z, Miziar i Halime, „Życie Tatarskie” 1935, nr 6; I. V o r e I, Dzisiaj jest Bajram, „Życie Tatarskie” 1935, nr 12; A. M u rza M u r zi c z, Minaret, „Życie Tatarskie” 1936, nr 2; E s te, Czarna róża (Tatareczka), „Życie Tatarskie” 1937, nr 1; C z o r B a t y r, Nie pomnę Cię Krymie, tamże, nr 4; Z. R y c k i e w i c z, Ataturk, „Życie Tatarskie” 1939, nr 6; A. W e r d a, Pan Bóg dał (pieśń kaukaskich muzułmanów przetłumaczona przez M. Gembickiego), „Życie Tatarskie” 1938, nr 7.

${ }^{51}$ W „Życiu Tatarskim” swoje artykuły umieszczali: Bohdan Achmatowicz - adwokat Sądu Okręgowego w Wilnie, Szamil Aljewicz - student Uniwersytetu im. Stefana Batorego, Maciej Bajraszewski - płk wojska polskiego i adwokat, Abduł Hamid Churamowicz - prezes i syn oficera byłego pułku tatarskiego, Jakub Bohdanowicz - dyrektor seminarium nauczycielskiego w Symferopolu, Ajaz Ishaki 
Wschodniej Europy - Kirimet Yigit emigrant azerbejdżański, dr Jakir Szakir emigrant azerbejdżański, Mirza Bała Tatar krymski. W gminach muzułmańskich i oddziałach ZKOTRP Tatarzy powoływali korespondentów, którzy przekazywali redakcji aktualne informacje o wydarzeniach w swojej społeczności52. Demokratyczny charakter umożliwiał każdemu udział w polemikach i dyskusjach na łamach czasopisma. W miesięczniku ukazywały się artykuły różnych autorów, co zapewne zróżnicowało poziom merytoryczny czasopisma. Jednak zadaniem „Życia Tatarskiego" nie było naukowe ujęcie rzeczywistości i poprawność merytoryczna tekstów, ale integracja społeczności tatarskiej, podniesienie jej poziomu wiedzy i szerzenie oświaty. Artykuły w przystępnym języku miały większą moc przekazu niż naukowe rozprawy.

Według Ministerstwa Wyznań Religijnych i Oświecenia Publicznego miesięcznik zasługiwał na subwencje ze względu na pogłębianie wiedzy religijnej, szerzenie wiedzy i dodatnie przyczynianie się do wychowania młodzieży. Pismo poświęcone zagadnieniom Wschodu Muzułmańskiego oraz przejawom życia społecznego i gospodarczego Tatarów polskich było ważnym czynnikiem na drodze wzajemnego zespolenia i utrwalenia sytuacji wielkiego narodu polskiego ${ }^{53}$.

$Z$ danych dotyczących prenumeraty wynika, że poziom czytelnictwa wśród społeczności tatarskiej nie był wysoki i mógł być tożsamy ze słabym rozwojem oświaty ${ }^{54}$. Wobec tak niskiego stanu czytelnictwa można stwierdzić, że „Życie Tatarskie" nie podnosiło poziomu kulturalno-oświatowego Tatarów polskich. Należy jednak zwrócić uwagę na fakt, iż czytanie miesięcznika nie jest równoznaczne $z$ jego prenumerowaniem i zakupem. W gminach muzułmańskich, w lokalnych oddziałach tatarskich podczas zebrań w świetlicach Tatarzy wspólnie czytali artykuły z „Życia Tatarskiego” lub pożyczali sobie miesięcznik ${ }^{55}$. Przekazywane wartości poznawcze inicjowały również dyskusje i poszerzały samoświadomość Tatarów.

\footnotetext{
- działacz tatarski z Powołża, Stefan Bazarewski - prof. Uniwersytetu Wileńskiego i prezes Gminy muzułmańskiej w Wilnie, Zofia Miśkiewiczówna - córka imama z Miru i nauczycielka języka francuskiego, Ajsza Muchówna - nauczycielka języka niemieckiego, Tamara Lebiedź - działaczka związkowa z Wilna, Halime Tuhan Baranowska - żona redaktora „Życia Tatarskiego”, Edige Szymkiewicz - prezes Rady Centralnej Kół Młodzieży Tatarskiej, Emir Tuhan Baranowski - historyk, bieżące sprawy międzynarodowe, Ali Połtorzycki - warszawski prawnik (student prawa), Jakub Szynkiewicz - mufti, Mustafa Gembicki - nauczyciel gimnazjum w Wilejce.

${ }^{52}$ W celu informowania na bieżąco o sprawach w Iwju Murawszczyźnie w 1935 r. powołano Sulejmana Rafałowicza na korespondenta, „Życie Tatarskie” 1936, nr 9, s. 21.

53 „Życie Tatarskie” 1934, nr 1, s. 16.

${ }^{54}$ Najwięcej czytelników (ok. 13,6\%) „Życia Tatarskiego” odnotowano w Wilnie, gdzie czasopismo było wydawane i gdzie na 100 Tatarów jedynie ok. 14 prenumerowało miesięcznik. W gminie nowogródzkiej na 100 osób jedynie jedna prenumerowała „Życie Tatarskie”. W Mirze, Klecku, Lachowiczach czy Słonimie, czyli w ośrodkach o wysokim poziomie działalności kulturalno-oświatowej „Życie Tatarskie” prenumerowało jedynie ok. 3\% mieszkańców. M. G e m b i c ki, Z życia Tatarów nowogródzkich, „Życie Tatarskie” 1938, nr 6, s. 2.

${ }_{55}$ Informator S. J., ur. 1917 r., Wywiad przeprowadzony przez U. Wróblewską 23 V 2006 r. w Białymstoku.
} 


\section{„Przegląd Islamski”}

Kolejnym periodykiem o charakterze oświatowym, zawierającym treści religii muzułmańskiej i integrującym społeczność tatarską był „Przegląd Islamski” Redakcja czasopisma mieściła się w Warszawie, redaktorem naczelnym był Wassan-Girej Dżabagi uchodźca z Kaukazu Północnego ${ }^{57}$, w gronie komitetu redakcyjnego byli: płk Kazun-Bek z Kaukazu, Olgierd Najman Mirza Kryczyński prezes Rady Centralnej ZKOTRP, Ali Ismail Woronowicz imam warszawski58. „Przegląd Islamski” jako kwartalnik ukazywał się w latach 1930-1931 oraz 1934-193759. Głównym celem czasopisma o profilu religijno-kulturalnym było pogłębienie znajomości islamu w Polsce [...] oraz zacieśnienie węzłów przyjaźni, jakie łączą od dawna naród polski z islamem"60.

Zamierzeniem redakcji było umieszczanie na łamach „Przeglądu Islamskiego" artykułów propagujących idee islamu oraz ukazujących kulturę muzułmańską. Wydawcy w periodyku chcieli umieszczać również prace poświęcone muzułmanom polskim - ich organizacji, religii, świątyniom czy mizarom ${ }^{61}$. Zgodnie z za-

56 „Przegląd Islamski” miał format B-5 o tekturowej stronie tytułowej, koloru jasnozielonego bez elementów dekoracyjnych. Zawartość „Przeglądu Islamskiego” pod względem ilustracji i zdjęć była bardzo skromna. W nielicznych tylko numerach spotykamy zdjęcia osób związanych z tym czasopismem, a także osobistości świata islamskiego. Na pierwszej stronie mieściła się nazwa czasopisma, a także spis treści, na samym dole zamieszczono miejsce wydania z adresem oraz cenę pojedynczego numeru i prenumeraty rocznej. W przeważającej mierze ilość stron była stała i wynosiła 16. Objętość czasopisma była zwiększona w numerach łączonych. Każdego roku kolejność zeszytów była liczona od numeru 1 do 4. Wyjątek stanowią dwa lata przerwy 1932-1933. Rok 1931 posiadał tylko zeszyt podwójny numer 1-2, obejmujący miesiące styczeń-czerwiec. Dalszych zeszytów brak jest w zbiorach bibliotecznych. Por. B. H. B I a d o c h, Analiza treści prasy islamskiej w II Rzeczypospolitej, „Rocznik Tatarów Polskich” 2001/2002, t. VII, s. 58; S. M i l c z a r e k, "Przegląd Islamski» (Prasa muzułmańsko-tatarska w Polsce cz. II), „Rocznik Tatarów Polskich” 1994, t. II, s. 248.

57 Wassan-Girej Dżabagi ur. 3 maja 1882 r. na Kaukazie Północnym. Po ukończeniu w 1900 r. szkoły realnej we Władykaukazie Północnym rozpoczął studia na Politechnice w Rydze, które kontynuował na Uniwersytecie w Petersburgu. W Instytucie Rolnictwa przy Uniwersytecie w Jenie uzyskał dyplom inżyniera agronoma. W wyniku wybuchu rewolucji powraca do ojczyzny, gdzie od 1917 r. walczy o suwerenność narodu jako członek Centralnego Komitetu Narodów Kaukazu Północnego. W 1919 r. po zajęciu Republiki przez generała Denikina decyduje się na emigrację i podejmuje walkę o wolność narodów Kaukazu w Paryżu, współpracując z przedstawicielami Republiki Kaukazu Północnego podczas Konferencji Pokojowej w Wersalu. 10 marca 1922 r. już jako mąż polskiej Tatarki przyjeżdża do Polski. Od 1923 r. pracuje jako dziennikarz, zajmując się sprawami Kaukazu i Wschodu. Jako korespondent „Kuriera Warszawskiego” wyjeżdża do Turcji. Po powrocie w 1926 r., jako specjalista od spraw Wschodu, współpracuje z „Kurierem Warszawskim”, „Polską Zbrojną”, „Polską Gospodarczą”, „Sprawami Obcymi”, „Drogą”. Od września 1927 r. wydaje biuletyn prasowy "Orient” poświęcony zagadnieniom krajów bałtyckich, bałkańskich, Rosji oraz Bliskiego Wschodu. W 1937 r. rezygnuje z redagowania „Przeglądu Islamskiego” i jako korespondent Polskiej Agencji Telegraficznej wyjeżdża do Turcji. „Przegląd Islamski” 1973, nr 4, s. 1-2.

58 „Życie Muzułmańskie” 1986, nr 1, s. 7.

59 W pierwszych latach „Przegląd Islamski” był jedynie muzułmańskim czasopismem polskim o profilu religijnym, który z powodu trudnych warunków finansowych w latach 1932-1933 zaprzestał swojej działalność. Od 1934 r. zostaje przypisany i wydawany już jako organ muzułmańskiej gminy m. st. Warszawy. „Wschód - Orient” 1933, nr 3-4, s. 72.

60 „Przegląd Islamski” 1936, nr 1-3, s. 9.

61 Mizar (miziar - u Tatarów polsko-litewskich) - cmentarz. 
miarem Kolegium Redakcyjnego w czasopiśmie miały również znajdować się artykuły poświęcone zabytkom orientalnym w Polsce oraz aktualności, przeglądy bibliograficzne, nekrologi działaczy muzułmańskich i dostojników państwowych, sprawozdania z konferencji oraz prace statystyczne ${ }^{62}$. Prasa muzułmańska wydawana w Warszawie bardziej ukazywała życie tatarskiej emigracji i stanowiła rdzenny element ich tożsamości ${ }^{63}$. W czasopiśmie umieszczano sprawozdania informujące o aktualnych wydarzeniach dotyczących społeczności muzułmańskich $^{64}$. Uaktualnieniem wiedzy były przeglądy bibliograficzne i recenzje książek ${ }^{65}$ ukazujące kierunki zainteresowań badawczych nad społecznością muzułmańską. Liczne prace omawiały również kulturę społeczności muzułmanów polsko-litewskich $^{66}$. W „Przeglądzie Islamskim” drukowano artykuły propagujące religię ${ }^{67}$,

62 Pięć lat naszej pracy, „Przegląd Islamski” 1936, nr 1-3, s. 10.

63 O. Kry czyń ski, Pamięci Ali Mazdan-Beka Tobczybaszego, „Przegląd Islamski” 1934, nr 3-4; t e nż e, Dżafer Bej Sejdamet, tamże, nr 3-4; Pogrzeb Aleksandra Sulkiewicza, „Przegląd Islamski” 1935, nr 3-4; L. K r y c z y ń s k i, Pamięci Tadeusza (Seyfeddina) Gasztowta, „Przegląd Islamski” 1936, nr 1-3.

64 W. G. Dża b a g i, Obecna sytuacja i statystyka Islamu, „Przegląd Islamski” 1934, nr I; L. K r y c z y ń s k i, tamże, nr 2; Audiencja u Pana Prezydenta Rzeczypospolitej, „Przegląd Islamski” 1935, nr 3-4; Uroczystości na zamku, „Przegląd Islamski” 1936, nr 1-3; Adres dziękczynny z powodu utworzenia szwadronu tatarskiego, tamże, nr 4; Pięć lat naszej pracy, tamże, nr 1-3; Utworzenie stałego poselstwa egipskiego w Warszawie, tamże, nr 1-3; O uregulowaniu stanu prawnego wyznania muzułmańskiego w Polsce, „Przegląd Islamski” 1934, nr 3-4.

65 Gramatyka arabskiego w języku polskim, „Przegląd Islamski” 1934, nr 3-4; T. K o w a I s k i, Na szlakach islamu, „Przegląd Islamski” 1935, nr 3-4; H. S. S z a p s z ał, Wyobrażenia świętych muzułmańskich a wpływy ikonograficzne w Persji i stosunki polsko-perskie za Zygmunta III, „Przegląd Islamski” 1936, nr 1-3; Wersetów z Koranu, (tłum. z arab. J. Szynkiewicz), tamże.

${ }^{66}$ W. G. D ż a b a g i, Muślimowie polscy, „Przegląd Islamski” 1930, nr I; L. K r y c z y ń s k i, Organizacja Muftiatu w Polsce, tamże, nr 3; t e n ż e, Zabytki orientalne $w$ Wilnie, tamże, nr 4; S. Z a t o r s k i, Wiadomości historyczne o minarecie w Warszawie przy ulicy Książęcej, „Przegląd Islamski” 1931, nr 1-2; t e n ż e, Miscelanea historyczne, tamże; A. W o r o n o w i c z, Cmentarze muzułmańskie w Widzach, tamże; Nowy meczet w Kownie, „Przegląd Islamski” 1934, nr I; S. K r y c z y ń s k i, Zygmunt August a Tatarzy litewscy, tamże, nr 3-4; Tatarzy na Litwie, tamże; L. K r y c z y ń s k i, Historia meczetów w Łowczycach i Nowogródku, tamże; S. K r y c z y ń s k i, Nieudana misja katolicka wśród muzułmanów litewskich w XVI w., „Przegląd Islamski” 1935, nr 3-4; t e n ż e, Jakób Tarak Murza Buczacki, tamże; L. K r y c z y ń s k i, Meczet w Niekraszuńcach, „Przegląd Islamski” 1936, nr 2-3; t e nż e, Jak carat zwalczał polskość w życiu religijnym Tatarów litewskich, tamże, nr 4; S. K ry c z y ń s ki, Ze starych modlitewników, tamże; L. K r y c z y ń s ki, Emigracja tatarska w Ameryce, tamże; Historia meczetu w Wilnie, „Przegląd Islamski” 1937, nr 1-3.

67 S a d r-u d-d i n, Poczucie jedności islamskiej, „Przegląd Islamski” 1930, nr I; H. R a s z y d, Duchowieństwo w Islamie, „Przegląd Islamski”, tamże; Muzułmanie czy Mahometanie, tamże; H. A. B u s zt a I in a, Szerjat - islamskie prawo cywilne, tamże, nr 2; F. K. C h a n a D u r a ni, Co to jest Islam, tamże, nr 3; W. G. D ż a b a g i, Stanowisko kobiety muzułmańskiej według Koranu, tamże, nr 4; t e nż e, Pielgrzymka do domu Allaha, „Przegląd Islamski” 1931, nr 1-2; Znaczenie pielgrzymki do Mekki, tamże; Islam pod względem cywilizacji i moralności, „Przegląd Islamski” 1934, nr 1-2; t e n ż e, Tolerancja w Islamie, tamże, nr 2; Uniwersalność Islamu, tamże; Koran o stworzeniu świata i ludzi, tamże; Wahhabici, tamże; Co myślano w Europie w Średniowieczu o Islamie i Proroku Muhammedzie, tamże; Islam a Europa, tamże; Napoleon a Islam, tamże; Mistyka w Islamie, tamże; Chutba, tamże; W. G. D ż a b a g i, Islam a wiedza, tamże, nr 3-4; A. W o r o n o w i c z, Objawienie w Islamie, „Przegląd Islamski” 1935, nr 1-2; t e n ż e, Islam na Dalekim Wschodzie, „Przegląd Islamski” 1934, nr 3; M. A l e k s a n d r o w i c z, Islam a nacjonalizm, „Przegląd Islamski” 1935, nr 1-2; Kazanie Proroka Mu-hammeda, tamże; Z ruchu islamistycznego w Egipcie, tamże; W. G. D ż a b a g i, 
omawiające kulturę muzułmańską i politykę narodowościową islamskich grup etnicznych ${ }^{68}$. Stałym fragmentem informacyjnym „Przeglądu Islamskiego” była „Kronika krajowa” i „Kronika zagraniczna”, gdzie w skróconej formie zamieszczano wzmianki z ówczesnego życia codziennego społeczności tatarskiej. Informowano o podróżach zagranicznych muftiego Jakuba Szynkiewicza, relacjonowano przyjazdy znaczących muzułmanów, wspominano zjazdy i spotkania tatarskie, przypominano o znaczeniu i potrzebie budowy meczetu w Warszawie. „Kronika krajowa" ukazywała przebieg oraz efekty działalności oddziałów ZKOTRP. Zaś „Kronika zagraniczna” zawierała informacje dotyczące Tatarów mieszkających w innych państwach. Ukazywano aspekty społeczno-polityczne państw arabskich i dążenia niepodległościowe grup etnicznych zamieszkujących Rosję.

Autorami artykułów zamieszczanych w „Przeglądzie Islamskim” byli rodzimi Tatarzy polscy oraz emigranci i uchodźcy z Powołża i Krymu, którzy stanowili większą część muzułmanów w Warszawie ${ }^{69}$.

Czasopismo ze względu na różnych autorów artykułów charakteryzowało się zróżnicowanym poziomem merytorycznym. Cechą „Przeglądu Islamskiego” było jego misyjno-propagandowe znaczenie, które podważa obiektywność treści ${ }^{70}$. Warto jednak podkreślić, że niektóre artykuły ze względu na znaczące informacje faktograficzne były przedrukowywane w czasopismach zagranicznych ${ }^{71}$.

\section{Podsumowanie}

Analizując treści zawarte w artykułach, można wyróżnić zasadnicze obszary tematyczne ${ }^{72}$ : idee islamskie (dział islamistyczny); kultura muzułmańska i po-

Stosunek Zachodu do Islamu, tamże, nr 3-4; M. Ch. G. W a j s o w, Czy można tłumaczyć Koran, tamże; W. G. D ż a b a g i, Budzący się Islam, „Przegląd Islamski” 1936, nr 1-3; O tłumaczeniu treści Koranu, tamże; Potęga Islamu, tamże, nr 4; M. A l e k s a n d r o w i c z, Co mówi Koran o Jezusie?, tamże.

${ }^{68}$ Mufti palestyński o cywilizacji zachodniej i wschodniej, „Przegląd Islamski” 1934, nr 1-2; S. K r y c z y ń s k i, Turcja a Powstanie Listopadowe, tamże; Historia ściany płaczu, tamże; Ibn Saud, nowoczesny zdobywca arabski, tamże; Dzieje Półksiężyca, tamże, nr 2; M. A l e k s a n d r o w i c z, Tysiąclecie Firdousiego, „Przegląd Islamski” 1931, nr 3-4; Dzieje księgozbioru Ptolemeuszy w Aleksandrii, „Przegląd Islamski” 1935, nr 1-2; Omar Chajjam, tamże; A. W o r o n o w i c z, Musa ibn Majmun (Mojżesz Majmonides), „Przegląd Islamski” 1935, nr 3-4.

${ }^{69}$ W kwartalniku pojawiały się rozważania i rozprawy Leona Arsłan Najman Kryczyńskiego, OIgierda Kryczyńskiego, Stanisława Kryczyńskiego, Wassana-Girej Dżabagi, prof. chemii UW Osmana Achmatowicza, płk. Kazum-Bek Tatara z Krymu, O. Fazalejewa Tatara nadwołżańskiego, prof. USB Stefana Bazarewskiego, Mustafa Aleksandrowicza i Ali Ismail Woronowicza.

70 J. R e y c h m a n, Mahomet i świat muzułmański, Warszawa 1958, s. 254-255.

${ }^{71}$ W miesięczniku wydawanym w Paryżu „La Pologna” z 1 lutego 1934 r. ukazał się artykuł Leona Bohdanowicza pt. Les Tatares on Pologna. Jako rezultat pobytu Czemałowicza w Wilnie ukazał się w numerze z dnia 25 marca 1934 r. wydawanego w Sarajewie pisma „Islamski Suijet” artykuł o polskich muzułmanach z reprodukcją fotografii z pobytu Prezydenta Rzeczypospolitej w meczecie wileńskim - por. „Przegląd Islamski” 1934, nr 2, s. 23.

${ }^{72}$ S. M i l c z a r e k, „Przegląd Islamski” (Prasa muzułmańsko-tatarska w Polsce cz. II), „Rocznik Tatarów Polskich" 1994, t. II, s. 250-252. 
lityka narodowościowa islamskich grup etnicznych; dzieje i kultura społeczności tatarskiej; wiadomości statystyczne, sprawozdania, aktualności i informacje praktyczne; wspomnienia, biografie i nekrologi działaczy muzułmańskich; przeglądy bibliograficzne i recenzje książek.

W każdym czasopiśmie inne było natężenie występowania wymienionych obszarów tematycznych, co w znacznej mierze zależało od profilu, idei, zadania i docelowej grupy czytelników. Charakter czasopisma był zaakcentowany już w samym jego tytule. „Rocznik Tatarski” jako zbiór esejów był reprezentacyjnym źródłem wiedzy o społeczności tatarskiej. W porównaniu z innymi czasopismami muzułmańsko-tatarskimi okresu międzywojennego „Rocznik Tatarski” koncentrował się głównie na sprawach związanych z historią i przeszłością Tatarów. Zadaniem „Życia Tatarskiego" było kształtowanie życia społecznego, kulturalnego i religijnego społeczności tatarskiej. Rozpowszechnianie zasad wiary i moralności oraz ukazywanie kart z historii Tatarów stanowiło często jedyne źródło ich wiedzy. Skierowane do wszystkich upowszechniało oświatę wśród społeczności tatarskiej. „Życie Tatarskie” dla społeczności miało znaczenie wychowawcze, oświatowe, ale również integracyjne. „Przegląd Islamski” zaliczany do prasy muzułmańskiej był bardziej skierowany do przedstawicieli emigracji mieszkającej w Warszawie.

Treści prasy wpisywały się $w$ realizowane postulaty i ideologie wychowania reprezentowane przez czołowych działaczy tatarskich. Czasopisma i publikacje ze względu na swoją treść oraz zasięg pośrednio przyczyniały się do przekazywania wiedzy i upowszechniania wartości w społeczności tatarskiej. Przekazywane w czasopismach treści miały podnosić świadomość i poziom wiedzy Tatarów polskich. Z jednej strony podkreślano przynależność do Polski jako ojczyzny, ale jednocześnie przywoływano elementy różniące Tatarów od reszty społeczeństwa.

Tematy artykułów skupione były wokół trzech zagadnień dotyczących religii, etniczności i państwowości, które jednocześnie stanowiły fundament wielowymiarowej tożsamości tatarskiej. Kreowanie Tatarów, jako wyznawców islamu i obywateli polskich było ważnym elementem prometeizmu w realizowanej polityce zagranicznej państwa polskiego.

Treści zawarte w czasopismach o charakterze propagandowym nie mogą stanowić obecnie głównego źródła wiedzy o społeczności tatarskiej w Drugiej Rzeczypospolitej, jednak po wnikliwej krytyce umożliwiają stworzenie obrazu życia społecznego Tatarów, a zróżnicowanie artykułów wskazuje kierunek rozwoju pracy oświatowej wśród społeczności tatarskiej. 